\title{
LOCATIONS OF DENS WITH RESPECT TO SPACE USE, PRE- AND POST-DENNING MOVEMENTS OF BROWN BEARS IN THE RUSSIAN FAR EAST
}

\author{
Ivan V. Seryodkin ${ }^{1, *} \mathbb{D}$, John Paczkowski ${ }^{2}$,John M. Goodrich ${ }^{3}$, Yuri K. Petrunenko1 ${ }^{\mathbb{D}}$ \\ ${ }^{1}$ Pacific Geographical Institute of FEB RAS, Russia \\ *e-mail:seryodkinivan@inbox.ru \\ ${ }^{2}$ Alberta Environment and Parks, Canada \\ ${ }^{3}$ Panthera Foundation, USA
}

Received: 12.12.2020. Revised: 18.02.2021. Accepted: 30.03.2021.

\begin{abstract}
Space use and the use of a den during the winter period as an adaptation of the brown bear (Ursus arctos) to increase survival during a period of food shortage, are important aspects of the ecology in the practice of the population management. Despite this, the subject of the den locations in relation to space use of brown bears and movements associated with a den entry and exit were practically not considered by researchers. Using radio-telemetry methods between 1993-2012, we studied the space use of 15 brown bears in SikhoteAlin, three in Kamchatka and two on Sakhalin. The location of 25 dens of tagged animals was determined. The majority of brown bears, mostly males, used space further from the den than from the average of all locations, and the overwhelming majority of dens were outside the core area of their home ranges. So, for brown bears, the spatial location of dens was away from preferred locations in the non-denning period. The same brown bears selected den sites in different denning seasons, both at relatively small distance from each other $(1.3 \mathrm{~km})$ and at a considerable distance $(20.2 \mathrm{~km})$. Females on Sakhalin moved to dens 7-9 days before the den entry. After leaving their dens, two females in Kamchatka moved 1.7 and $5.0 \mathrm{~km}$ on the first day, while on Sakhalin, two females did not move more than $0.1 \mathrm{~km}$ from their dens for the first 4 and 10 days. Female that gave birth to cubs in the denning period lingered the longest at the den. The distance of females from their dens and their movement activity decreased in the pre-denning period (10 days before denning, the variations in movement stabilised at a low level) and increased in the post-denning period (specifically after 10 days from the moment of emergence).
\end{abstract}

Key words: daily movements, denning location, home range, population management, spatial ecology, Ursus arctos

\section{Introduction}

In the Russian Far East, Ursus arctos Linnaeus, 1758 (hereafter - brown bear, or bear) plays a considerable role in ecosystems and is of great practical importance for humans (Revenko, 1993; Yudin, 1993). The brown bear populations in this region are relatively prosperous. However, they need competent management to ensure their preservation.

An important ecological characteristic of a population is the space use by animals (Dahle \& Swenson, 2003; Rigg, 2005; Popescu et al., 2017), which in turn is associated with the distribution of food, the availability of breeding opportunities and resting locations. The presence and distribution of places suitable for denning is also of great importance for the brown bear. The denning period is an important part of the brown bear's life, since it contributes not only to the experience of unfavourable food availability, but also includes such important events as the pregnancy of females and the birth and rearing of offspring (His- sa, 1997). Brown bears spend a considerable part of their life in dens, an average of 146 days, in the Sikhote-Alin region (Seryodkin et al., 2003), while in the north of the Russian Far East it is up to 210 days (Chernyavskiy et al., 1993). Knowledge of the specifics of space use by animals and the ecology of the denning period is important for the development of a plan for the conservation and rational use of the brown bear.

In connection with the above, much attention is paid to the study of dens and hibernation of brown bears throughout their range in Eurasia and North America. Traditionally, studies are focused on describing the types of dens and their design (Camarra, 1997; Huber \& Roth, 1997; Elfström \& Swenson, 2009), determining the length of the denning period and factors affecting its timing (Danilov, 1991; Manchi \& Swenson, 2005; Krofel et al., 2017), the study of denning site selection by animals (Vroom et al., 1980; Danilov, 1991; Petram et al., 2004), including the effect of anthropogenic factors on the 
location of dens (Elfström et al., 2008; Elfström \& Swenson, 2009). To detect brown bear dens, related timing of den entry and exit, researchers effectively use radio-telemetry (Craighead \& Craighead, 1972a; Seryodkin et al., 2003; Elfström et al., 2008; Krofel et al., 2017). Studies devoted to the analysis of brown bear den selection in relation to the used space have not previously been specifically conducted. Some aspects on this topic were presented only in publications on brown bears in Sweden (Manchi \& Swenson, 2005) and Bulgaria (Todorov et al., 2020). Earlier, for brown bears from the Russian Far East, some issues of spatial ecology were highlighted, including the use of home ranges, daily and seasonal movements (Seryodkin et al., 2014, 2017, 2019). Nevertheless, the location of the dens, and the movements associated with the entry and exit from the dens, were not taken into account in these studies. The present study is intended to supplement scientific knowledge of this issue for the Russian Far East as well as for the whole range of the brown bear.

The aim of this study was to identify the characteristics of space use by brown bears in connection with their choice of den sites. The objectives of the study were to determine the locations of dens in relation to the area used by brown bears during the non-denning period, to describe the location of dens in relation to the home ranges and core areas of animals, to determine the relative locations of dens over multiple winters and to identify the characteristics of the movements of brown bears in the pre- and postdenning periods.

\section{Material and Methods}

The study was carried out within the framework of programs on the study and conservation of brown bears in Sikhote-Alin (Seryodkin et al., 2019), Kamchatka (Seryodkin \& Paczkowski, 2009) and on Sakhalin (Seryodkin et al., 2012) with the participation of the Pacific Geographical Institute of FEB RAS, the Wildlife Conservation Society, the Sikhote-Alin State Nature Reserve, the Kronotsky State Nature Reserve and the Sakhalin Environment Watch Regional Public Organisation.

The studies were carried out in the Primorsky Krai in the Middle Sikhote-Alin territory (1993-2002); in the Kamchatsky Krai in the Kronotsky State Nature Reserve, and in the River Kamchatka basin (2005-2006); in the
Sakhalin Region in the Vostochny Sanctuary (2011-2012) (Fig. 1). The territory of all regions is dominated by mountainous terrain. On the Sikhote-Alin, pine-broad-leaved and fir-spruce forests are typical and broad-leaved forests on the sea coast (Pimenova, 2016). In Kamchatka, habitats of the brown bear are represented by birch forests, riparian floodplains, and sprucelarch forests, coastal meadows, dwarf thickets, plains and mountain tundra (Revenko, 1993). On Sakhalin, the main vegetation type is the dense fir-spruce forest (Tolmachev, 1955).

The capture of animals for the purpose of radio-marking was carried out with Aldrich snares and free-range dart immobilisation. The first method of brown bear trapping is used widespread in the world (e.g. Jonkel, 1993). The Aldrich snare is a steel cable tightened on the animal's paw with the help of a spring. Another end of the cable is fixed, but it rotates freely on a swivel, which reduces the likelihood of injury to the animal. Snare sites were set on trails or near bait (fish, pieces of ungulates). The second method consisted of approaching a brown bear, which is unafraid and allows a person to approach at a close distance, and immobilising it with a dart (Seryodkin \& Paczkowski, 2006).

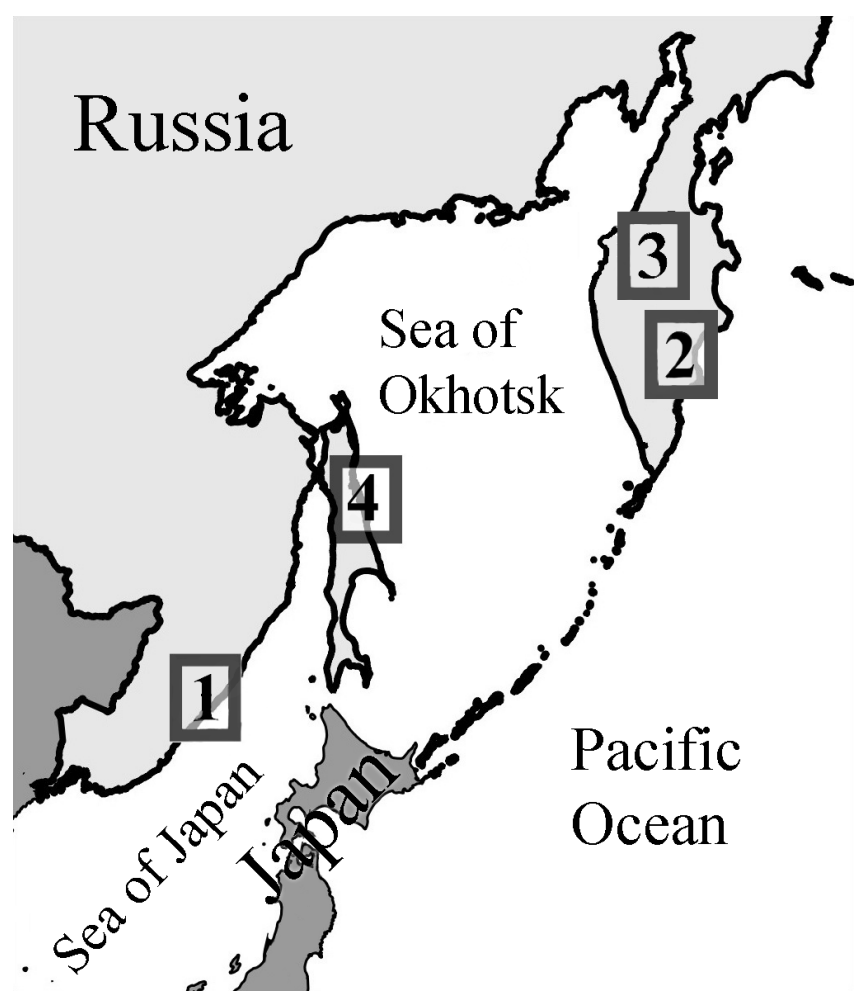

Fig. 1. Radio-telemetry study areas of brown bears (Ursus arctos) in the Russian Far East. Designations: 1 - Middle Sikhote-Alin, 2 - Kronotsky State Nature Reserve, 3 - River Kamchatka basin, 4 - Vostochny Sanctuary. 
Brown bears were immobilised using Telinject and Pneu-Dart guns. Zoletil was used as an immobilisation agent (Zoletil, Virbac, France; $50 \%$ tiletamine hydrochloride $+50 \%$ zolazepam hydrochloride) in recommended doses (Kreeger, 1996; Seryodkin et al., 2005).

The sex and age of the immobilised animals were determined. The age of the animals was assessed by the number of growth lines in the dental cementum of the anterior premolars (Klevezal, 1988).

In 1993-2001 in Sikhote-Alin, nine male and six female brown bears (numbers of 1-15) were caught and equipped with VHF (very high frequency) radio collars of the MOD-400 and MOD-500 systems (Telonics, Mesa, Arizona, USA). In 2005, female №16 and female №17 were caught in the valley of Geysers (Kronotsky State Nature Reserve). The male №18 was captured in 2005 near Lake Two-Yurt (River Kamchatka basin). In 2011, in the River Vengeri basin (Vostochny Sanctuary, Sakhalin Region), female №19 and female №20 were captured. Brown bears in Kamchatka and Sakhalin were equipped with LOTEK GPS 4400 collars (Lotek Wireless, Inc., Ontario, Canada).

In the Sikhote-Alin territory, brown bears were tracked using a radio receiver (TR-2, Telonics, Mesa, Arizona), directional H-antennas (RA-2A, Telonics, Mesa, Arizona, USA) and three-segment Yagi antennas (RA-17, Telonics, Mesa, Arizona, USA). The radio-receiving equipment was tuned to the individual frequencies of the radio-collar transmitters. The search for brown bears was carried out on foot routes or using Mi-2 and Mi-8 helicopters and An-2 aircraft. The co-ordinates of the animals in Kamchatka and Sakhalin were determined using a GPS-receiver built into the collar. Co-ordinates were obtained by downloading the memory card after the collar was returned. For brown bears №16, №17, №18, the devices were programmed for one location every $3 \mathrm{~h}$, and for animals №19 and №20, once an hour. The collars of animal №16 and animal №17 were retrieved using a remotely controlled drop off mechanism. Brown bears №19 and №20 were re-captured for the equipment removal procedure. Brown bear №18 has dropped the collar on its own.

We analysed 742 locations of brown bears in Sikhote-Alin, 3123 in Kamchatka, and 8112 in Sakhalin (Table 1) using no more than one position of one animal per day. Due to the large number of the sampled locations from animals with GPS collars (i.e. individuals with number 16-20), results for these animals are discussed in more detail than for brown bears fitted with VHF radio-collars (i.e. individuals with number 1-15). The duration of brown bears' ob- servations lasted from 142 days (male №2) to 1241 days (female №8). The location of each den was included in the sampling of locations only once.

The locations of 25 dens were identified. In the Sikhote-Alin, three brown bears used more than one den: two dens were used by male №4 (winters of 1993/1994 and 1994/1995), four dens were used by female №8 (winters 1996/1997, 1997/1998, 1998/1999, and 1999/2000) and two dens were used by male №13 (winters 1999/2000 and 2000/2001). The timing of the denning period for each animal was determined using radio and GPS telemetry. The seasons corresponded to the calendar spring, summer, autumn and winter.

The home ranges of all observed brown bears were previously analysed (Seryodkin et al., 2017, 2019). The spatial contours of the home ranges of brown bears were drawn using the fixed kernel method (Van Winkle, 1975; Worton, 1989). The method consists of statistical calculation of the animal location probability at any point in the investigated space with a probability from $1 \%$ to $100 \%$. The home range was considered as an area with a $95 \%$ probability of finding the animal. For core areas of home ranges (space with relatively high intensity of use by animals) calculation, we used the kernel circuit, wherein the difference between the expected and actual areas would be at a maximum (Powell, 2000). Given the use of the 95\% probability, not all locations were included in the home range, so the den could be located outside the $95 \%$ home range.

Polygons of long-term home ranges and their core areas (annual and over a longer period) were obtained for all individuals. For brown bears from Kamchatka and Sakhalin, seasonal home ranges of the non-denning period were also calculated: for females №16 and №17, spring, summer and autumn home ranges were calculated; for male №18, summer and autumn home ranges were calculated; for females №19 and №20, spring, two summers (2011 and 2012) and autumn home ranges were calculated.

For each brown bear, the mean value (location) of all co-ordinates was used in the location analysis. For each location within a sample from one animal, the distance from the location to the den and to the mean location of all co-ordinates was calculated. For each brown bear, we identified a statistically significant difference between the distance to each location from the den and the distance to each location from the mean of all locations. For comparison between the categories of animals, combined by sex or region, we used medians of the ratio of the distance of each location from the den to the distance of each location from the mean of all locations. This ratio indicates the spatial distribution of locations closer to the den, if it 
is $<1$, or closer to the mean co-ordinates, if the value is $>1$. In the presence of different dens of the same individual (№4, №8, №13), the analysis used one home range for the entire observation period, since the sample size did not allow for the selection of individual annual home ranges. For statistical analysis, the use of non-parametric statistical tests was justified. Shapiro-Wilk test ( $\mathrm{W}=2-5985300, p<0.05)$ and histograms showed that data were not normally distrib- uted and Bartlett test (Bartlett's $\mathrm{K}^{2}=38$ 893, $\mathrm{df}=24$, $p<0.001)$ revealed no equality of their variances. Analysis of samples requiring pairwise comparison was performed using the Mann-Whitney U-test. For samples consisting of several categories, significance of differences was determined by the Kruskal-Wallis test (Kruskal \& Wallis, 1952), and further pairwise comparison completed with the Mann-Whitney U test with a Bonferroni correction.

Table 1. Characteristics of GPS-collared and radio-collared brown bears in the Russian Far East, with observation data and the position of the dens relative to locations outside of dens

\begin{tabular}{|c|c|c|c|c|c|c|c|c|}
\hline \multirow{3}{*}{$\begin{array}{l}\text { Animal } \\
\text { № }\end{array}$} & \multirow{3}{*}{$\begin{array}{c}\text { Sex, age (years) } \\
\text { at the beginning } \\
\text { of observation }\end{array}$} & \multirow{3}{*}{$\begin{array}{l}\text { Observation } \\
\text { period }\end{array}$} & \multirow{3}{*}{$\begin{array}{l}\text { Number of } \\
\text { locations }\end{array}$} & \multicolumn{2}{|c|}{$\begin{array}{c}\text { Median of remoteness of } \\
\text { locations, } \mathrm{km}\end{array}$} & \multirow{3}{*}{$\begin{array}{c}\text { Median of } \\
\text { remoteness of } \\
\text { locations, } \mathrm{km}\end{array}$} & \multirow{2}{*}{\multicolumn{2}{|c|}{$\begin{array}{l}\text { The results of the Mann-Whitney U-test at } \\
\text { the comparison of locations' remoteness from } \\
\text { the den and from the mean of all locations }\end{array}$}} \\
\hline & & & & \multirow{2}{*}{$\begin{array}{l}\text { from the mean } \\
\text { of all locations }\end{array}$} & \multirow{2}{*}{ from the den } & & & \\
\hline & & & & & & & W & $p$ \\
\hline \multicolumn{9}{|c|}{ Middle Sikhote-Alin $\left(45.0^{\circ} \mathrm{N}, 136.0^{\circ} \mathrm{E}\right)$} \\
\hline 1 & 0,9 & $\begin{array}{l}05.07 .1993- \\
27.07 .1995\end{array}$ & 37 & 15.8 & 17.5 & 2.02 & 412 & 0.001 \\
\hline 2 & o, 11 & $\begin{array}{l}19.07 .1993- \\
08.12 .1993 \\
\end{array}$ & 21 & 20.1 & 48.0 & 2.46 & 114 & 0.02 \\
\hline 3 & o, $2-3$ & $\begin{array}{l}03.09 .1993- \\
10.09 .1994 \\
\end{array}$ & 87 & 3.2 & 54.7 & 17.36 & 7 & $<0.001$ \\
\hline 4 & o, 12 & $\begin{array}{l}10.09 .1993- \\
10.06 .1995 \\
\end{array}$ & 110 & $7.7,7.7$ & $9.6,25.3$ & $1.45,3.75$ & 4405,334 & $<0.001$ \\
\hline 5 & o, 16 & $\begin{array}{l}19.05 .1994- \\
06.05 .1995 \\
\end{array}$ & 32 & 12.0 & 20.1 & 2.21 & 165 & $<0.001$ \\
\hline 6 & 0,8 & $\begin{array}{c}31.05 .1994- \\
25.05 .1995 \\
\end{array}$ & 34 & 7.4 & 9.6 & 1.44 & 385 & 0.04 \\
\hline 7 & ㅇ, 7 & $\begin{array}{l}04.06 .1994- \\
09.07 .1997 \\
\end{array}$ & 49 & 17.4 & 15.0 & 1.59 & 1265 & 0.41 \\
\hline 8 & +, 9 & $\begin{array}{c}13.06 .1996- \\
06.11 .1999 \\
\end{array}$ & 34 & $3.5,3.5,3.8,3.5$ & $\begin{array}{c}14.8,4.4 \\
4.0,5.6\end{array}$ & $\begin{array}{l}3.68,1.38 \\
1.32,1.60\end{array}$ & $\begin{array}{c}88,491,531 \\
434\end{array}$ & $<0.001,0.5,0.87,0.16$ \\
\hline 9 & ㅇ, 4 & $\begin{array}{c}11.06 .1997- \\
13.07 .1998\end{array}$ & 45 & 3.7 & 11.8 & 3.23 & 54 & $<0.001$ \\
\hline 10 & ㅇ, 8 & $\begin{array}{c}17.09 .1999- \\
15.08 .2001 \\
\end{array}$ & 60 & 9.8 & 4.8 & 0.58 & 2661 & $<0.001$ \\
\hline 11 & 0,8 & $\begin{array}{l}23.10 .1999- \\
27.10 .2001\end{array}$ & 28 & 45.5 & 52.8 & 1.11 & 351 & 0.82 \\
\hline 12 & †, 9 & $\begin{array}{l}31.10 .1999- \\
28.08 .2000 \\
\end{array}$ & 68 & 1.9 & 2.5 & 1.52 & 1749 & 0.03 \\
\hline 13 & 0,8 & $\begin{array}{c}31.10 .1999- \\
23.11 .2000\end{array}$ & 61 & $8.3,8.3$ & $36.2,33.9$ & $4.53,4.27$ & 427,492 & $<0.001$ \\
\hline 14 & j, 13 & $\begin{array}{l}19.05 .2000- \\
12.04 .2002 \\
\end{array}$ & 46 & 7.0 & 30.0 & 4.29 & 2 & $<0.001$ \\
\hline 15 & ㅇ, 3 & $\begin{array}{l}31.05 .2001- \\
23.06 .2002 \\
\end{array}$ & 30 & 4.5 & 5.5 & 1.63 & 342 & 0.23 \\
\hline \multicolumn{9}{|c|}{ Kamchatka, Kronotsky State Nature Reserve $\left(54.4^{\circ} \mathrm{N}, 160.1^{\circ} \mathrm{E}\right)$} \\
\hline 16 & ๆ, $8-10$ & $\begin{array}{l}05.06 .2005- \\
06.06 .2006 \\
\end{array}$ & 1281 & 4.5 & 2.4 & 0.53 & 981560 & $<0.001$ \\
\hline 17 & q, $>12$ & $\begin{array}{c}05.06 .2005- \\
06.06 .2006\end{array}$ & 1089 & 1.0 & 5.8 & 5.13 & 121990 & $<0.001$ \\
\hline \multicolumn{9}{|c|}{ Kamchatka, River Kamchatka basin $\left(56.8^{\circ} \mathrm{N}, 160.0^{\circ} \mathrm{E}\right)$} \\
\hline 18 & o, 5 & $\begin{array}{c}23.06 .2005- \\
09.05 .2006 \\
\end{array}$ & 753 & 15.2 & 31.0 & 2.2 & 217490 & $<0.001$ \\
\hline \multicolumn{9}{|c|}{ Sakhalin, Vostochny Sanctuary $\left(50.6^{\circ} \mathrm{N}, 143.6^{\circ} \mathrm{E}\right)$} \\
\hline 19 & ㅇ, 3-4 & $\begin{array}{c}21.06 .2011- \\
24.08 .2012 \\
\end{array}$ & 4022 & 1.8 & 1.5 & 1.09 & 8780800 & $<0.001$ \\
\hline 20 & o*, $6-7$ & $\begin{array}{c}26.06 .2011- \\
26.08 .2012 \\
\end{array}$ & 4090 & 1.0 & 1.4 & 1.57 & 5985300 & $<0.001$ \\
\hline
\end{tabular}

Note: * until August 2011, the female bear had a three-year-old cub; in 2012, she had two young-of-year cubs. Multiple values for one individual indicate the detection of several dens in different denning seasons. 
Using regular GPS-locations, we assessed the movement patterns of brown bears in the pre-denning season for females from Sakhalin and in the post-denning season for females from Kamchatka and Sakhalin. We used the daily distance of the animal from the den and the daily movement, which is the sum of linear displacements between locations per day. The first indicator demonstrates the distance of the brown bear from the den, and the second indicator shows its physical activity in the given periods of the time. To analyse movements relative to the den location and the denning duration, we used the data from 30 days before the animals entered and 30 days after they left the den. We compared data by five-day intervals ( $1-5$ days, $6-10$ days, $11-15$ days, 16-20 days, 21-25 days and 26-30 days). Statistical evaluation was carried out using the Kruskal-Wallis test. When differences were significant, interval comparisons were made using the Mann-Whitney U-test with Bonferroni correction. Correlation analysis was used to identify relationships between median diurnal movement of brown bears and the distance to the den within five-day intervals for each of four females. $95 \%$-confidence intervals of correlation coefficients $(95 \% \mathrm{CI})$ were obtained using a bootstrap of 10000 repetitions.
Statistical analysis of data was carried out using the R v. 3.5.2 (R Core Team, 2020), and graphic processing and geometric calculations - in the QGIS program, v. 3.4.1 (Open Source Geospatial Foundation, Switzerland). In the Electronic Supplement, we present this paper in the Russian language to make it more available for Russian researchers.

\section{Results}

\section{The location of dens in the used space}

For most dens of radio-collared brown bears (16 out of 25), the distance of all the locations from the den were significantly greater than the distance from the mean of all locations when comparing the medians (Fig. 2). This implies the den location is usually selected further from the locations the animal used during the entire non-denning period (Fig. 3). In other words, the locations selected during the non-denning period are located more compactly in relation to each other than in relation to the den. This pattern was more common in males, nine of which denned further than the mean locations ( $\mathrm{W}=2-217490, p<0.05)$. Only for male №11, significant differences were not revealed $(\mathrm{W}=351, p=0.82)$, despite the fact that his median distance of the locations to the den was longer than the median distance from the mean locations (Table 1).

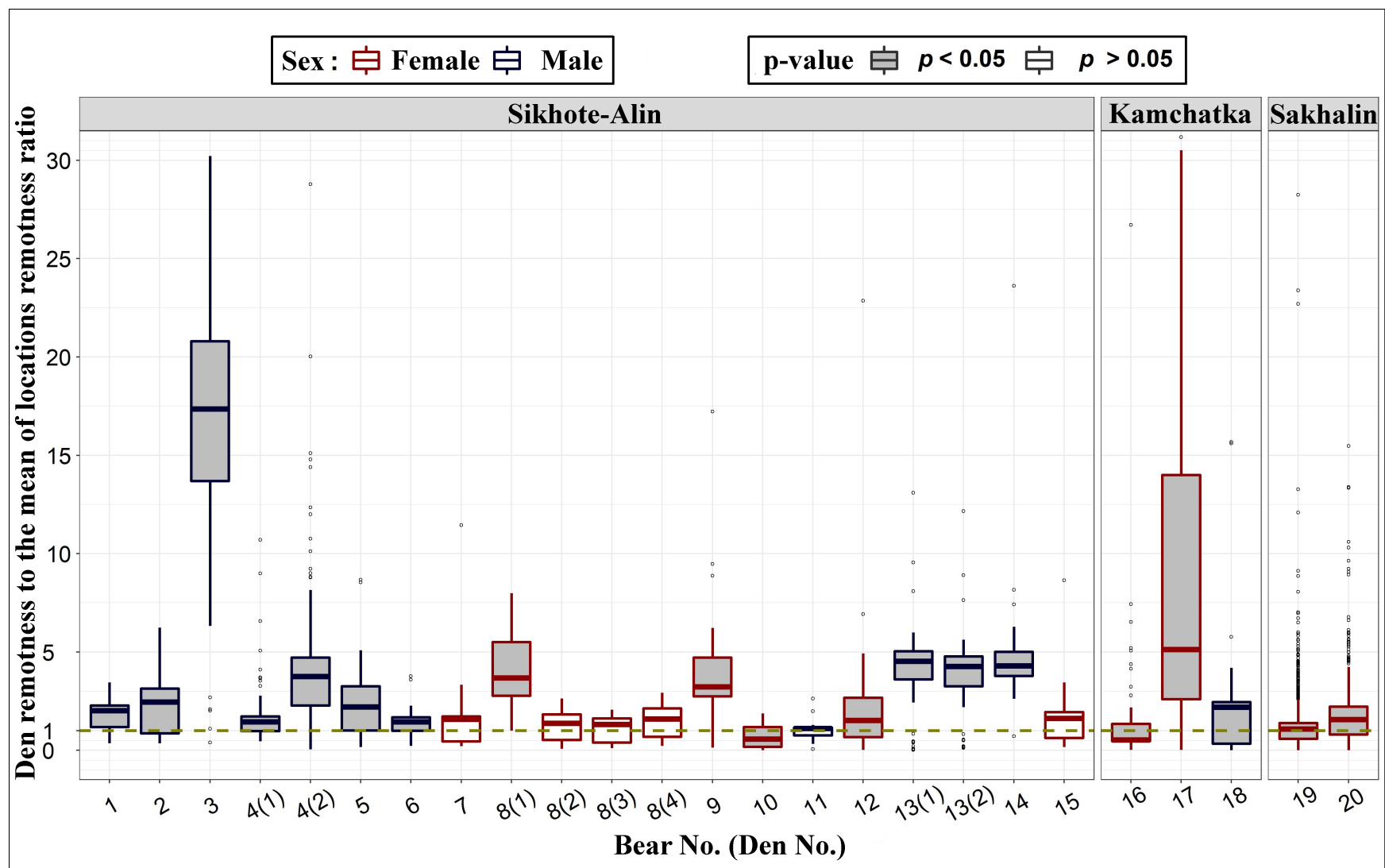

Fig. 2. The ratio of the remoteness of the den (distance of the den from each telemetry location) to the remoteness of the mean of all locations (distance of all locations to the mean of all co-ordinates) in the space used by brown bears in the Russian Far East. The dashed horizontal line is the border; values below this border indicate the shift of locations towards the den; values above this border show the shift of locations towards the mean of all locations. 


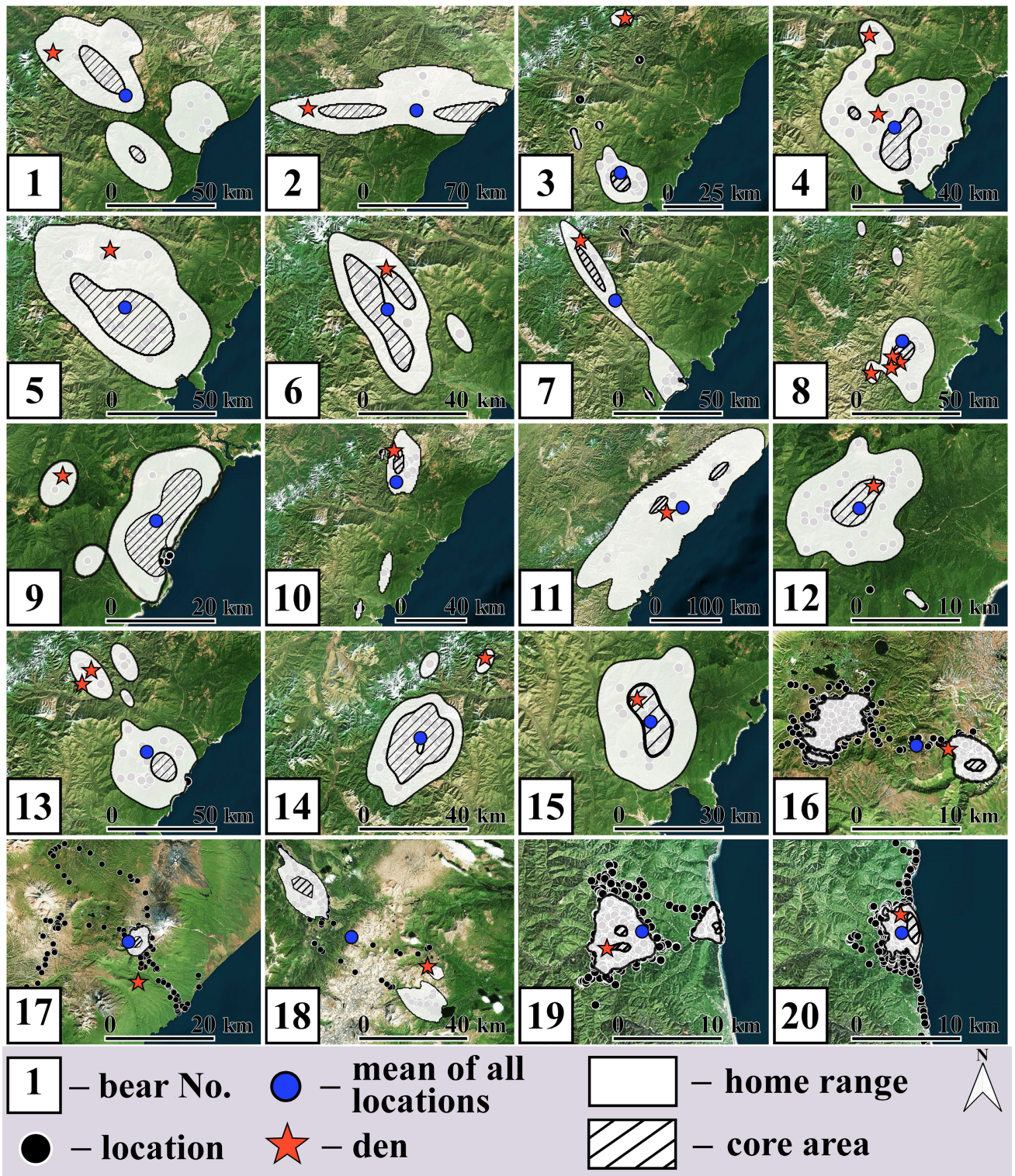

Fig. 3. Locations of dens in relation to the used space of collared brown bears in Sikhote-Alin, Kamchatka and Sakhalin.

In females, the opposite selection was revealed with respect to the location of dens. For six females (№8, №9, №12, №17, №19, №20), and for most males, the distance of locations from dens was significantly longer than the remoteness of locations from the mean of all locations ( $\mathrm{W}=54-8780800$, $p<0.05$ ), conversely for two females (№10, №16), the second indicator was higher than the first (W $=2661-981560, p<0.001)$. For the rest of the females, no significant differences were found, while for female №8, the differences were only for one of the four dens used.

The ratio of the remoteness of locations from the den to the remoteness from the mean of the locations was the highest in male №3 on SikhoteAlin (Table 1, Fig. 2), and the den of this animal was at a far distance from other locations (Fig. 3). The distance from the den to the nearest location was $15.2 \mathrm{~km}$, and more than $50 \mathrm{~km}$ to the main cluster of locations. The den of female №17 in the Kronotsky Nature Reserve was also relatively isolated (Fig. 3). The remoteness of the locations from the den was in 5.13 times greater than the remoteness from the mean of locations (Table 1).

The medians of the ratios of remoteness of locations from den to the remoteness from the mean locations of males (2.34) were greater than in females (1.57). Analysis of data between all males and females (independently of the studied region) revealed that the males have dens at a relatively longer distance compared to females $(\mathrm{W}=24, p$ $<0.05)$. At the same time, no differences were found between females from different regions $(\mathrm{H}=0.65, \mathrm{df}=2, p=0.7)$.

When comparing the indicators of the remoteness of locations from the den and the remoteness 
of locations from the mean of locations for individuals with several dens, significant differences $(p<0.001)$ were found between the samples of two dens for male №4 and female №8 in the 1996/1997 denning season compared to the other three seasons. Thus, male №4, with a significant relative distance from both dens, one of them (season 1994/1995) was significantly farther from the mean of all locations compared to the second (season 1993/1994). In female №8, three dens were equidistant from the mean of locations, while the fourth was at a considerable distance from the mean of locations and other dens. In the samples of two dens of male №13, no differences were found, which indicates the equidistance of his two dens from the mean of all locations. In Fig. 3, there is evidence of such distribution of dens, and for male №13 and three dens of female №8, their location in the same direction from the mean of locations and mutual relative proximity were clearly demonstrated.

\section{The location of dens in relation to home ranges}

Of 20 observed brown bears, 18 (except for individuals №3 and №17) dens were located within the home range polygons $(95 \%$ probability of occurrence), but ten of these animals located their 11 dens on the periphery sites (Fig. 3). At the same time, seven brown bears, whose dens were located outside the polygons or on their periphery, were males, and five were females. In the core area of the home range, there were only seven dens of six brown bears. The remaining ones were outside the area intensively used by animals. Only one of these dens belonged to a male (№6), while the others to females.

In Kamchatka, female №17 had a den outside all three seasonal (spring, summer, and autumn) home ranges. The den of female №16 was out of the spring and summer areas, by locating within the autumn home range, but not within its core area. The den of male №18, was in the autumn home range polygon, but outside the summer one. Only on Sakhalin, both females (№19, №20) had dens within all polygons of their seasonal home ranges, with the exception of the 2012 summer season for female №20.

\section{Distribution of dens for one individual}

The shortest distance between dens of one individual was for female №8 in the winter seasons of $1997 / 1998$ and $1998 / 1999$ at $1.3 \mathrm{~km}$. The average distance between four dens of female №8 was $6.1 \mathrm{~km}(\mathrm{SD}=5.0 \mathrm{~km})$. The maximum distance between dens of one brown bear was for male №4 (Table 2, Fig. 3), $20.2 \mathrm{~km}$.

\section{Peculiarities of brown bear movements in the pre-denning period}

On Sakhalin, female №19 seven days prior to the den entry, which occurred on 16.11.2011, was no further than $1.4 \mathrm{~km}$ from the future denning site, while two days before denning, it was no further than $0.3 \mathrm{~km}$ from this site. Female №20 spent nine days before denning (31.10.2011) no further than $0.17 \mathrm{~km}$ from the future denning site, and during the last day maintained at a distance not exceeding $0.07 \mathrm{~km}$ from the future den. Thus, the females observed on Sakhalin moved to the area where the den was established 7-9 days before denning, and on the last days they were in the immediate vicinity of the denning site.

For female №20, the distance to the den in the last two five-day intervals was significantly less than in the other four preceding intervals $(p<0.05)$. In addition, for 11-15 days before the den entry, the female was closer than in 16-20 days and 26-30 days intervals $(p<0.05)$. The daily movements in the periods preceding denning were less than in the periods more distant from the den entry (Fig. 4). The last five days of movement by female №19 differed by less movement of the animal's activity compared with the intervals 16-20 days, 21-25 days and 26-30 days before the den entry $(p<0.05)$. For female №20, the movement activity was lower during the two intervals preceding the den entry in comparison with all other intervals $(p<0.05)$.

Table 2. Distance between dens in different denning seasons in radio-collared brown bears in the Sikhote-Alin territory

\begin{tabular}{|c|c|c|c|c|c|}
\hline \multirow{2}{*}{ Brown bear № (den number) } & $4(2)$ & $8(2)$ & $8(3)$ & $8(4)$ & $13(2)$ \\
\hline & \multicolumn{5}{|c|}{ The distance between the dens, $\mathrm{km}$} \\
\hline $4(1)$ & 20.2 & - & - & - & - \\
\hline $8(1)$ & - & 10.7 & 11.4 & 9.7 & - \\
\hline $8(2)$ & - & - & 1.3 & 1.7 & - \\
\hline $8(3)$ & - & - & - & 1.8 & - \\
\hline $13(1)$ & - & - & - & - & 3.7 \\
\hline
\end{tabular}

Note: Denning seasons: 4 (1) - 1993/1994, 4 (2) - 1994/1995, 8 (1) - 1996/1997, 8 (2) - 1997/1998, 8 (3) - 1998/1999, 8 (4) - 1999/2000, 13 (1) - 1999/2000, 13 (2) - 2000/2001. 


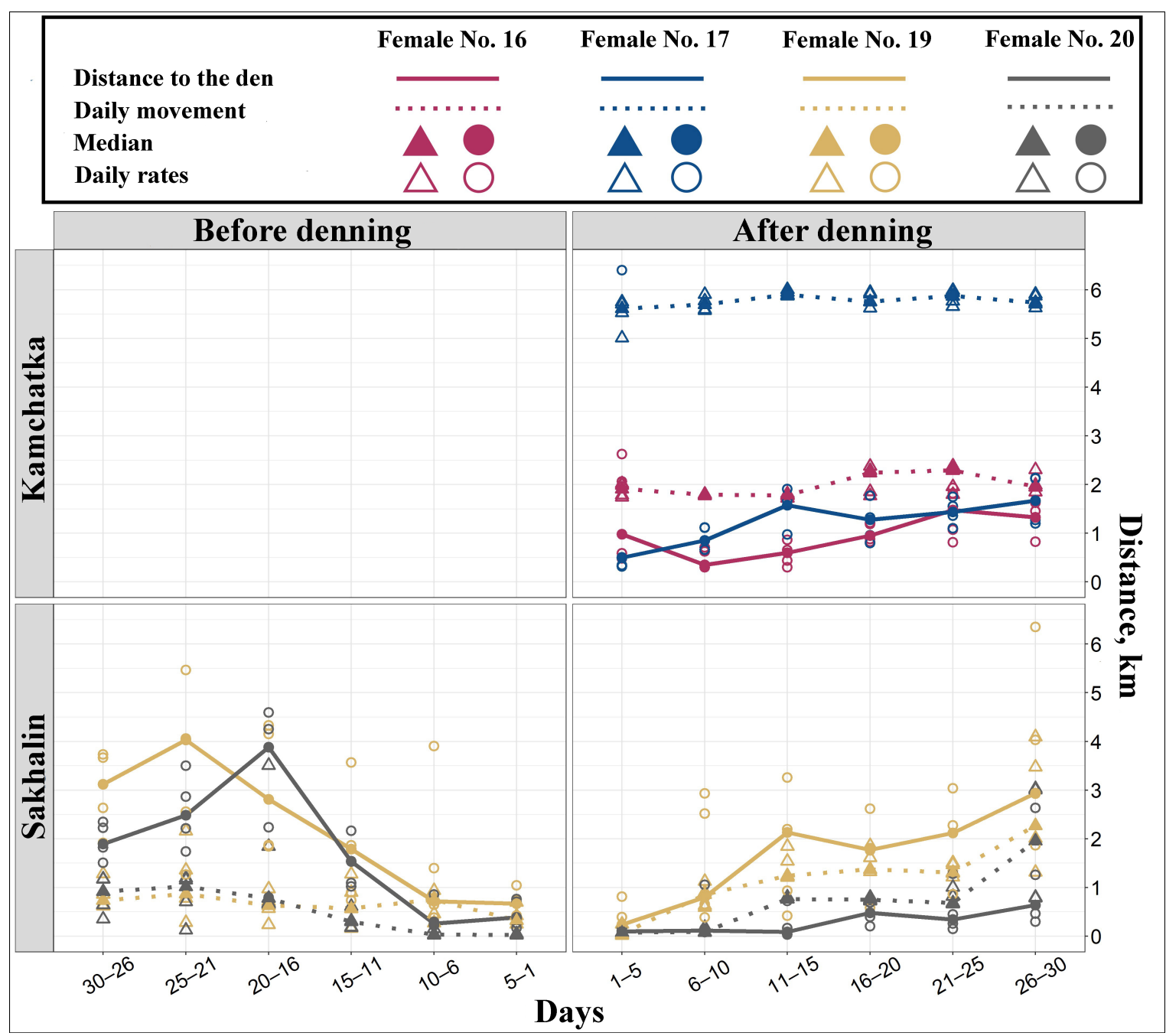

Fig. 4. Distance from dens and movement activity of female brown bears prior to entering and after leaving the dens in Kamchatka and Sakhalin.

In general, in the 30-day period when approaching denning, female №20 reduced its distance to the den $(r=0.94,95 \%$ CI $0.55-0.99, \mathrm{t}=5.56, \mathrm{df}=4$, $p<0.01$ ), while female №19 reduced its mobility $(r=0.91,95 \%$ CI $0.38-0.99, \mathrm{t}=4.42, \mathrm{df}=4$, $p=0.01$ ). In the pre-denning period for female №20, the distance to the den correlated with the daily movements $(r=0.80,95 \%$ CI $-0.04-0.97, \mathrm{t}=2.63, \mathrm{df}=4$, $p<0.05)$. For two female bears on Sakhalin, similar trends were observed in the movement activity (Fig. $4)$ in the period preceding the den entry $(r=0.77$, $95 \%$ CI $-0.10-0.97, \mathrm{t}=2.44, \mathrm{df}=4, p<0.05)$.

Peculiarities of brown bear movements in the post-denning period

In Kamchatka, both females made movements on the first day after leaving the den. After leaving the den, female №16 (27.04.2006) moved away from the den to $1.7 \mathrm{~km}$, while female №17 moved $5.0 \mathrm{~km}$ on the first day after leaving the den (07.05.2006). For female №16, in the period from six-ten days and from 11-15 days, the distance to the den decreased compared to the intervals from $21-30$ days $(\mathrm{H}=14.19, \mathrm{df}=5, p<0.05)$. For the same period (6-15 days after leaving the den), the diurnal movement of the female was significantly less extensive than in the intervals from 16-30 days $(\mathrm{H}=15.88, \mathrm{df}=5, p<0.05)$.

On Sakhalin, after leaving the den (17.04.2012), female №19 was no further than $0.05 \mathrm{~km}$ during four days. Only on the fifth day, this bear moved to $0.25 \mathrm{~km}$, and in the next 10 days, its distance from the den increased every day. After leaving the den (16.04.2012), female №20 was no further than 0.09 $\mathrm{km}$ from the den during the first nine days. Only on the $11^{\text {th }}$ day, the bear began to move more than 0.7 $\mathrm{km}$ from the den.

In the first two five-day intervals, females №19 and №20 were closer to the den than in subsequent intervals $(\mathrm{H}=23.72, \mathrm{df}=5, p<0.05$ for female №19, and $\mathrm{H}=23.61$, $\mathrm{df}=5, p<0.05$ for female №20). In the first five days after leaving the den, 
the movement was less than in the subsequent fiveday intervals (Fig. 4) for female №19 in the period 16-30 days after leaving the den $(\mathrm{H}=15.11$, $\mathrm{df}=5, p<0.05$ ).

After leaving the den, there was a gradual increase in distance to the den by female №19 $(r=0.93$, 95\% CI 0.47-0.99, $\mathrm{t}=4.99, \mathrm{df}=4, p<0.01)$ and female №20 ( $r=0.87,95 \%$ CI $0.21-0.99, \mathrm{t}=3.56$, $\mathrm{df}=4, p<0.05)$, as well as the movement activity of female №17 ( $r=0.86,95 \%$ CI $0.15-0.98, \mathrm{t}=3.34$, $\mathrm{df}=4, p<0.05)$, female №19 $(r=0.93,95 \%$ CI $0.48-0.99, \mathrm{t}=5.02, \mathrm{df}=4, p<0.01)$, and female №20 $(r=0.87,95 \%$ CI $0.20-0.99, \mathrm{t}=3.52, \mathrm{df}=4$, $p<0.01$ ) (Fig. 4). Trends in changing the distance from the den over the 30-day period after leaving the den were similar between female №19 and female №20 ( $r=0.92,95 \%$ CI $0.42-0.99, \mathrm{t}=4.66$, $\mathrm{df}=4, p<0.01$ ), while trends in movement activity were similar between female №17 and female №19 $(r=0.98,95 \%$ CI $0.81-0.99, \mathrm{t}=9.51, \mathrm{df}=4$, $p<0.001)$. For females №17, №19 and №20, the distance to the den correlated with the bear's daily movements $(r=0.80-0.95,95 \%$ CI $-0.04-0.99$, $\mathrm{t}=2.65-6.08, \mathrm{df}=4, p<0.05)$.

\section{Discussion \\ The location of dens in the used space}

The results show that brown bears, especially males, deliberately move to distant areas for denning in relation to their places of non-denning. Apparently, this is caused by the spatial separation of the denning sites with other ones, primarily foraging sites. Females are less susceptible to such movements, because, in general, long-distance movements are less typical for females than males, which is also observed in other brown bear populations (Mano, 1994; McLoughlin et al., 1999).

Among the females, in which the distance of recorded locations from the dens was significantly longer than the distance from the mean of all locations, female №20 from the Vostochny Sanctuary gave birth to two cubs during staying in the den. The relative isolation of the den location could be supported by increased requirements for the protective spatial properties of the den in relation to the birth and rearing of offspring. Brown bears most often have dens in hard-to-reach places; this makes them less likely to be disturbed by humans and predators (Petram et al., 2004; Elfström et al., 2008; Seryodkin et al., 2018a).

The location of dens in relation to home ranges

The location of dens in relation to home ranges and their calculated core areas suggests that in brown bears, primarily males, the choice of den locations is not always or insignificantly related to the locations used during the non-denning period. In brown bears, for which seasonal polygons were analysed, the den was more often included in polygons of autumn home ranges, compared to summer and spring home ranges. Apparently, this could be related with the inclusion in the autumn season brown bears' locations, while the animals were searching for and building their dens. For some individuals, the choice of a den location is influenced by their locations during feeding during autumn.

We are aware of only two studies assessing the locations of dens in relation to brown bear home ranges. On the Balkan Peninsula, in contrast to our study, almost all dens of brown bears were inside of the home range core areas, and four out of nine individuals established dens in the centre of the core area (Todorov et al., 2020). This suggests that brown bears may have different preconditions regarding the choice of den locations. On the Balkan Peninsula, the choice of the den locations was apparently influenced by the presence of artificial feeding stations, where animals fed for most of the year. In Scandinavia, $43 \%$ of the dens were in the core area zones of the animal's home ranges, and the other ones were outside this area. The authors of this study did not find any pattern in the location of dens (Manchi \& Swenson, 2005). Nevertheless, there is evidence that the brown bear female in North America, over the course of eight years of observations, selected dens outside of the annual home ranges (Craighead, 1976). The study of Ursus americanus Pallas, 1780 (hereafter - black bear) in Alberta (Canada) showed that dens of females were located on the periphery of home ranges, while males' dens were outside their home ranges (Tietje \& Ruff, 1980), which correspond to our results and observations.

\section{Distribution of dens for one individual}

The spatial distribution of dens belonging to one individual can be of a different nature. The brown bear can make dens in different denning seasons either close to each other or at a considerable distance. For example, female №8 shows that some of the dens can be located close to each other, while individual dens can be located at a certain distance from preferred places for denning.

In Scandinavia, the average distance between brown bear dens of young dispersing males was $59.1 \mathrm{~km}$, while for adult males and females, it had lower values (11.6 km and $4.9 \mathrm{~km}$ respectively). In this study, the maximum distance between two dens 
of young males was $357 \mathrm{~km}$ (Manchi \& Swenson, 2005). Nonetheless, adult brown bears in Scandinavia have shown a high degree of «fidelity» to certain denning places within their annual home ranges. The close proximity of three dens in female №8 and two dens in male №13 in our study (Table 2, Fig. 3) confirms the conclusion about the adherence of brown bears to the re-use of the same denning places. This may be caused by the desire of animals to return to well-known den areas, in comparison with those where they had no experience of successful denning.

The fidelity of brown bears to certain areas can be explained by the presence of suitable conditions. The factors determining the choice of such places are the characteristics of the relief, microclimate and protective properties of the study area. Concentrations of brown bear dens have been observed under the most optimal conditions (Van Daele et al., 1990; Huber \& Roth, 1997; Seryodkin et al., 2018b). Mass purposeful movements of brown bears in the pre-denning period have been recorded to places with high den densities (Kostoglod, 1979; Zavatskiy, 1987; Yudin, 1993).

Despite brown bears usually setting up dens in different seasons, in close proximity to one another, repeated use of the same dens is rare. In this and other studies (e.g. Manchi \& Swenson, 2005), we did not find such observations. Nevertheless, it is known that Alaskan brown bears have used the same den repeatedly, including several years in a row (Van Daele et al., 1990).

\section{Peculiarities of brown bear movements in the pre- and post-denning periods}

Observations of marked brown bears demonstrate that the animal movements associated with the beginning and end of hibernation can be different. While on Sakhalin, females arrived in advance to the location of den sites arrangement, and did not leave them immediately after denning, being 5-9 days in the vicinity of the den, in Kamchatka, the females made significant transitions immediately after leaving the dens. This behaviour is possibly caused by the fact that in Kamchatka, denning sites are located far from foraging areas. In particular, in the River Shumnaya basin, we found a place where the dens were concentrated (Seryodkin et al., 2018b), including the den of female №17. However, the main home ranges of the females were in the vicinity of the valley of Geysers and geo-thermal zones, where there are favourable feeding conditions, especially in spring.

The pre-denning period is preceded by hyperphagia of brown bears. In the Sikhote-Alin, brown bears can make dens at a great distance from their autumn feeding sites (Abramov, 1972; Kucherenko, 1983; Yudin, 1993; Seryodkin et al., 2014). In North America, brown bears moved from the hyperphagia place to denning locations at $25.6 \mathrm{~km}$ away over 12 hours (Craighead, 1976). Nevertheless, monitoring in Sakhalin showed that for females, moving to denning places may occur beforehand, over short distances and gradually. Mobility with such behaviour in females also gradually decreases, and stabilises in the ten days prior to denning (Fig. 4). Thus, being in the surroundings of the den, the animals move less, apparently spending more time in inactive state, preparing to the long time of the hibernation period. Studies on Sikhote-Alin confirmed that brown bears are least active in the pre-denning (11.3\% of the time) and post-denning (34.4\% of the time) periods (Seryodkin et al., 2013). After hyperphagia, brown bears gradually reduce their activity and movement intensity before entering the den. This period usually lasts $1-2$ weeks (Friebe et al., 2001; Manchi \& Swenson, 2005; Sahlén et al., 2011), but can last more than a month (Servheen \& Klaver, 1983; Evans et al., 2016).

In North America, brown bears may also arrive in denning places weeks before and spend 3-7 days excavating and constructing the den (Craighead \& Craighead, 1972b; Brown, 1993). Black bears in Alberta also spend 5-10 days by establishing dens (Tietje \& Ruff, 1980). However, in other cases, brown bears come to den locations immediately prior to the den entry (Craighead \& Craighead, 1972b). Probably, due to experience and knowledge of the area, older animals spend less time in the area before the den entry than younger individuals (Sahlén et al., 2011).

Similar tendencies occur in females in Kamchatka and Sakhalin (in particular, the correlation in movement levels in the period after leaving the den, as well as similar tendencies in mobility during this period) allow suggesting that brown bears of different populations may develop common adaptive behavioural traits, associated with the den entry and leaving the den. Of them, the most obvious regularities are the following: i) the nature of the brown bear movements depends on the location of places suitable for denning; ii ) the movement activity of animals is reduced with an decrease in the distance from the den, as well as in the time before the den entry.

The prolonged stay of female №20 in the immediate surroundings of the den after the hibernation end is apparently associated with the offspring birth during denning, the presence of which limits 
movements of the family group. Similar observations (when females with newborn cubs left the surroundings of the den only a few weeks after leaving the den) were demonstrated for brown and black bears in North America (Lindzey \& Meslow, 1976; Haroldson et al., 2002).

\section{Conclusions}

Analysis of data based on the den location in relation to the used space have shown that brown bears, especially males, tend to choose den locations at some distance from places used during the non-denning period in the Russian Far East. This is explained by the fact that brown bears have special requirements for selecting dens, which may not correspond to the area used in the most parts of their home ranges. The brown bear movements in the pre- and post-denning periods are associated with the locations with favourable conditions for setting up dens and their distance from seasonal habitats used in spring and late autumn. The intensity of animal movements generally decreases with the approach of the den entry and increases in the post-denning period.

Analysis of the characteristics of habitats, nutrition and other aspects of the brown bear ecology can provide a more complete understanding of factors influencing the choice of sites for surviving during the winter and movements associated with dens. Nevertheless, our research contributes to the understanding of such an important issue for the conservation and rational use of brown bears as the ecology of the denning period. The denning period is the most critical for survival, since it is characterised by unfavourable food and weather conditions. In addition, this period is associated with the offspring birth.

Permanent and local den locations are important for the existence of the brown bear population. Restricting human access to such places helps to reduce stress and anxiety of animals during hibernation, which increases the survival rate of brown bears, including offspring (Goldstein et al., 2010; Mangipane et al., 2018; Iosif et al., 2020). The identification of key denning habitat could provide information on where we should avoid or limit habitat destruction, which helps facilitate brown bear management and conservation planning.

\section{Supporting Information}

The Russian-language version of this paper (Electronic Supplement. The version of the paper «Locations of dens with respect to space use, preand post-denning movements of brown bears in the
Russian Far East» presented in Russian) may be found in the Supporting Information.

\section{References}

Abramov V.K. 1972. Migrations of bears in the south of the Far East of the USSR. In: Ecology, morphology, protection and use of bears. Moscow: Nauka. P. 6-8. [In Russian]

Brown G. 1993. The Great Bear Almanac. New York: Lyons and Burford. $325 \mathrm{p}$.

Camarra J.J. 1997. Caractéristiques et utilisation de tanières hivernales d'ours brun (Ursus arctos) dans les Pyrénées. Gibier Faune Sauvage 4: 391-405.

Chernyavskiy F.B., Krechmar A.V., Krechmar M.A. 1993. The brown bear. The North of the Far East. In: Bears: brown bear, polar bear, Asian black bear. Moscow: Nauka. P. 318-348. [In Russian]

Craighead F.C. 1976. Grizzly bear ranges and movement as determined by radiotracking. International Conference on Bear Research and Management 3: 97-109. DOI: $10.2307 / 3872759$

Craighead F.C., Craighead J.J. 1972a. Data on grizzly bear denning activities and behavior obtained by using wildlife telemetry. International Conference on Bear Research and Management 2: 84-106. DOI: 10.2307/3872573

Craighead F.C., Craighead J.J. 1972b. Grizzly bear prehibernation and denning activities as determined by radiotracking. Wildlife Mongraphs 32: 3-35.

Dahle B., Swenson J.E. 2003. Home ranges in adult Scandinavian brown bears (Ursus arctos): effect of mass, sex, reproductive category, population density and habitat type. Journal of Zoology 260(4): 329-335. DOI: $10.1017 / \mathrm{S} 0952836903003753$

Danilov P.I. 1991. Brown bear dens in the USSR. In: Bears of the USSR, State of Populations. Rzhev: Rzhev Press. P. 56-70. [In Russian]

Elfström M., Swenson J.E. 2009. Effects of sex and age on den site use by Scandinavian brown bears. Ursus 20(2): 85-93.

Elfström M., Swenson J.E., Ball J.P. 2008. Selection of denning habitats by Scandinavian brown bears $U r$ sus arctos. Wildlife Biology 14(2): 176-187. DOI: 10.2981/0909-6396(2008)14[176:SODHBS]2.0.CO;2

Evans A.L., Singh N.J., Friebe A., Arnemo J.M., Laske T.G., Fröbert O., Swenson J.E., Blanc S. 2016. Drivers of hibernation in the brown bear. Frontiers in Zoology 13: 7. DOI: $10.1186 /$ s12983-016-0140-6

Friebe A., Swenson J.E., Sandegren F. 2001. Denning chronology of female brown bears in central Sweden. Ursus 12: 37-45.

Goldstein M.I., Poe A.J., Suring L.H., Nielson R.M., McDonald T.L. 2010. Brown bear den habitat and winter recreation in South-Central Alaska. Journal of Wildlife Management 74(1): 35-42. DOI: 10.2193/2008-490

Haroldson M.A., Ternent M.A., Gunther K.A., Schwartz C.C. 2002. Grizzly bear denning chronology and movements in the Greater Yellowstone Ecosystem. Ursus 13: 29-37.

Hissa R. 1997. Physiology of the European brown bear (Ursus arctos arctos). Annales Zoologici Fennici 34(4): 267-287. 
Huber D., Roth H.U. 1997. Denning of brown bears in Croatia. International Conference on Bear Research and Management 9(2): 79-83. DOI: 10.2307/3872664

Iosif R., Pop M.I., Chiriac S., Sandu R.M., Berde L., Szabó S., Rozylowicz L., Popescu V.D. 2020. Den structure and selection of denning habitat by brown bears in the Romanian Carpathians. Ursus 31e5: 1-13. DOI: 10.2192/URSUS-D-18-00010.1

Jonkel J.J. 1993. A manual for handling bears for managers and researchers. Bozeman, USA: U.S. Fish and Wildlife Service. $175 \mathrm{p}$.

Klevezal G.A. 1988. The recording structures of mammals in zoological studies. Moscow: Nauka. 288 p. [In Russian]

Kostoglod V.E. 1979. Surveys of bears at movements to wintering places in the Middle Sikhote-Alin. In: Ecological basis for conservation and sustainable use of carnivorous mammals. Moscow: Nauka. P. 224-225. [In Russian]

Kreeger T.J. 1996. Handbook of wildlife chemical immobilization. Wyoming: International Wildlife Veterinary Sciences, Inc. 342 p.

Krofel M., Špacapan M., Jerina K. 2017. Winter sleep with room service: denning behaviour of brown bears with access to anthropogenic food. Journal of Zoology 302(1): 8-14. DOI: 10.1111/jzo.12421

Kruskal W.H., Wallis W.A. 1952. Use of ranks in onecriterion variance analysis. Journal of the American Statistical Association 47(260): 583-621. DOI: 10.1080/01621459.1952.10483441

Kucherenko S.P. 1983. Ecology and hunting of the brown bear in the Far East. In: Ecology and Hunting Game. Moscow: Nauka. P. 123-131. [In Russian]

Lindzey F.G., Meslow E.C. 1976. Winter dormancy in black bears in southwestern Washington. Journal of Wildlife Management 40(3): 408-415. DOI: 10.2307/3799942

Manchi S., Swenson J.E. 2005. Denning behaviour of Scandinavian brown bears Ursus arctos. Wildlife Biology 11(2): 123-132. DOI: 10.2981/0909-6396(2005)11[123:DBO SBB]2.0.CO;2

Mangipane L.S., Belant J.L., Gustine D.D., Hilderbrand G.V., Mangipane B.A. 2018. Sex-specific variation in denning by brown bears. Mammalian Biology 93: 38 44. DOI: 10.1016/j.mambio.2018.08.001

Mano T. 1994. Home range and habitat use of brown bears in the southwestern Oshima Peninsula, Hokkaido. International Conference on Bear Research and Management 9(1): 319-325. DOI: 10.2307/3872717

McLoughlin P.D., Case R.L., Gau R.J., Ferguson S.H., Messier F. 1999. Annual and Seasonal Movement Patterns of Barren-Ground Grizzly Bears in the Central Northwest Territories. Ursus 11: 79-86.

Petram W., Knauer F., Kaczensky P. 2004. Human influence on the choice of winter dens by European brown bears in Slovenia. Biological Conservation 119(1): 129-136. DOI: 10.1016/j.biocon.2003.07.021

Pimenova E.A. (Ed.). 2016. Plants, fungi and lichens of the Sikhote-Alin State Nature Reserve. Vladivostok: Dalnauka. 557 p. [In Russian]

Popescu V.D., Iosif R., Pop M.I., Chiriac S., Bouroș G., Furnas B.J. 2017. Integrating sign surveys and telemetry data for estimating brown bear (Ursus arctos) density in the Romanian Carpathians. Ecology and Evolution 7(18): 7134-7144. DOI: 10.1002/ece3.3177

Powell R.A. 2000. Animal home ranges and territories and home range estimators. In: Research techniques in animal ecology: controversies and consequences. Irvington, New York: Columbia University Press. P. 65-110.

R Core Team. 2020. R: A language and environment for statistical computing. Vienna, Austria: R Foundation for Statistical Computing. Available from: https:// www.R-project.org/

Revenko I.A. 1993. The brown bear. Kamchatka. In: Bears: brown bear, polar bear, Asian black bear. Moscow: Nauka. P. 380-403. [In Russian]

Rigg R. 2005. A review of studies on brown bear (Ursus arctos) ecology in relation to home range, habitat selection, activity patterns, social organization, life histories and population dynamics. Oecologia Montana 14(1-2): 47-59.

Sahlén E., Støen O.G., Swenson J.E. 2011. Brown bear den site concealment in relation to human activity in Sweden. Ursus 22(2): 152-158. DOI: 10.2192/URSUS-D-10-00007.1

Servheen C., Klaver R. 1983. Grizzly bear dens and denning activity in the Mission and Rattlesnake Mountains, Montana. International Conference on Bear Research and Management 5: 201-207. DOI: 10.2307/3872539

Seryodkin I.V., Paczkowski J. 2006. Capture, immobilization and marking of brown bears in Kamchatka. In: Conservation of biodiversity of Kamchatka and coastal waters. Petropavlovsk-Kamchatsky: Kamchatpress. P. 203-206. [In Russian]

Seryodkin I.V., Paczkowski J. 2009. Program to study brown bears on Kamchatka with the goal of conservation. Proceedings of Samara Scientific Centre of RAS 11(1-2): 158-161. [In Russian]

Seryodkin I.V., Kostyria A.V., Goodrich J.M., Miquelle D.G., Smirnov E.N., Kerley L.L., Quigley H.B., Hornocker M.G. 2003. Denning ecology of brown bears and Asiatic black bears in the Russian Far East. Ursus 14(2): 153-161. DOI: $10.2307 / 3873015$

Seryodkin I.V., Kostyrya A.V., Goodrich J.M., Schleyer B.O., Miquelle D.G., Kerley L.L., Quigley K.S., Quigley H.B. 2005. Capture and immobilization of Asiatic black and brown bears for radio marking. Zoologicheskii Zhurnal 84(12): 1508-1515. [In Russian]

Seryodkin I.V., Lisitsyn D.V., Borisov M.Yu. 2012. Study of brown bear at Sakhalin. Proceedings of Samara Scientific Centre of RAS 14(1-8): 1925-1928. [In Russian]

Seryodkin I.V., Kostyria A.V., Goodrich J.M., Miquelle D.G. 2013. Daily activity patterns of brown bear (Ursus arctos) of the Sikhote-Alin Mountain Range (Primorskiy Krai, Russia). Russian Journal of Ecology 44(1): 50 55. DOI: 10.1134/S1067413613010104

Seryodkin I.V., Kostyria A.V., Goodrich J.M. 2014. Daily and seasonal movements of brown bear in the SikhoteAlin. Herald of Tver State University. Series: Biology and Ecology 4: 233-240. [In Russian]

Seryodkin I.V., Paczkowski J., Borisov M.Y., Petrunenko Y.K. 2017. Home ranges of brown bears on the Kam- 
chatka peninsula and Sakhalin Island. Contemporary Problems of Ecology 10(6): 599-611. DOI: 10.1134/ S1995425517060129

Seryodkin I.V., Miquelle D.G., Goodrich J.M., Kostyria A.V., Petrunenko Y.K. 2018a. Interspecific relationships between the Amur tiger (Panthera tigris altaica) and brown (Ursus arctos) and Asiatic black (Ursus thibetanus) bears. Biology Bulletin 45(8): 853-864. DOI: 10.1134/S1062359018080149

Seryodkin I.V., Zhakov V.V., Paczkowski J. 2018b. Brown bear (Ursus arctos) (Carnivora, Mammalia) dens of the Kronotsky Nature Reserve. Povolzhskiy Journal of Ecology 1: 101-105. DOI: 10.18500/1684-7318-2018-1-101-105

Seryodkin I.V., Kostyria A.V., Goodrich J.M., Petrunenko Y.K. 2019. Space use by brown bears (Ursus arctos) in the Sikhote-Alin. Journal of Siberian Federal University. Biology 12(4): 366-384. DOI: 10.17516/19971389-0308 [In Russian]

Tietje W.D., Ruff R.L. 1980. Denning behavior of black bears in boreal forest of Alberta. Journal of Wildlife Management 44(4): 858-870. DOI: 10.2307/3808314

Todorov V.R., Zlatanova D.P., Valchinkova K.V. 2020. Home range, mobility and hibernation of brown bears (Ursus arctos, Ursidae) in areas with supplementary feed- ing. Nature Conservation Research 5(4): 1-15. DOI: 10.24189/ncr.2020.050

Tolmachev A.I. 1955. Geobotanical zoning of Sakhalin Island. Moscow, St. Petersburg: AS USSR. 78 p. [In Russian]

Van Daele L.J., Barnes V.G., Smith R.B. 1990. Denning characteristics of brown bears on Kodiak Island, Alaska. International Conference on Bear Research and Management 8: 257-267.

Van Winkle W. 1975. Comparison of Several Probabilistic Home-Range Models. Journal of Wildlife Management 39(1): 118-123. DOI: $10.2307 / 3800474$

Vroom G.W., Herrero S., Ogilvie R.T. 1980. The ecology of winter den sites of grizzly bears in Banff National Park, Alberta. International Conference on Bear Research and Management 4: 321-330. DOI: 10.2307/3872887

Worton B.J. 1989. Kernel methods for estimating the utilization distribution in home-range studies. Ecology 70(1): 164-168. DOI: $10.2307 / 1938423$

Yudin V.G. 1993. The brown bear. The South of the Far East. In: Bears: brown bear, polar bear, Asian black bear. Moscow: Nauka. P. 348-380. [In Russian]

Zavatskiy B.P. 1987. Den entry dates and bear den types in the Yenisei taiga. In: Bear Ecology. Novosibirsk: Nauka. P. 84-91. [In Russian]

\title{
РАСПОЛОЖЕНИЕ БЕРЛОГ В ИСПОЛЬЗУЕМОМ ПРОСТРАНСТВЕ, ПРЕД- И ПОСТБЕРЛОЖНЫЕ ПЕРЕМЕЩЕНИЯ БУРЫХ МЕДВЕДЕЙ НА ДАЛЬНЕМ ВОСТОКЕ РОССИИ
}

\author{
И. В. Середкин ${ }^{1, *} \mathbb{D}$, Д. Пачковский ${ }^{2}$, Д. М. Гудрич ${ }^{3}$, Ю. К. Петруненко 1 \\ ${ }^{1}$ Тихоокеанский институт географии ДВО РАН, Россия \\ *e-mail: seryodkinivan@inbox.ru \\ ${ }^{2}$ Окружающая среда и парки Альберть, Канада \\ ${ }^{3}$ Фонд «Пантера», США
}

\begin{abstract}
Использование пространства и переживание снежного периода в берлоге как адаптация для повышения выживаемости в период нехватки кормов - аспекты экологии Ursus arctos (далее - бурого медведя), важные в практике управления его популяциями. Несмотря на это, вопросы расположения берлог относительно используемого бурыми медведями пространства и перемещений, связанных с залеганием и выходом из берлог, практически не рассматривались исследователями. В 1993-2012 гг. методом телеметрии изучали использование пространства 15 бурыми медведями на Сихотэ-Алине, тремя - на Камчатке и двумя - на Сахалине. Определено местоположение 25 берлог меченых животных. Места пребывания большинства бурых медведей, преимущественно самцов, были дальше от берлоги, чем от средней всех локаций, тогда как подавляющее число берлог находилось за пределами ядерных зон участков обитания. Таким образом, для бурых медведей характерно устройство берлог на удалении от предпочитаемых ими внеберложных мест обитания. Одни и те же бурые медведи выбирали места для берлог в разные сезоны, как на относительно небольшом расстоянии друг от друга (1.3 км), так и на значительном удалении (20.2 км). Самки на Сахалине перемещались к берлогам за 7-9 суток до залегания в них. Две самки на Камчатке совершили переход на 1.7 км и 5.0 км в первые сутки после выхода из берлог, тогда как на Сахалине две самки не отходили от берлог более чем на 0.1 км в течение четырех и десяти суток. Дольше всех у берлоги задержалась самка, родившая в данный берложный сезон медвежат. Удаленность самок от берлог и их двигательная активность уменьшались в предберложный период (за десять суток до залегания показатели стабилизировались на низком уровне) и увеличивались в постберложный период (особенно после десяти суток с момента выхода из берлоги).
\end{abstract}

Ключевые слова: Ursus arctos, берложная стация, пространственная экология, суточные перемещения, управление популяцией, участок обитания 